\title{
Transcatheter aortic valve implantation
}

\section{Ahmed Oliemy and Nawwar Al-Attar*}

\author{
Address: Department of Cardiac Surgery, Golden Jubilee National Hospital, Agamemnon Street, Clydebank, G81 4DY, Glasgow, UK \\ *Corresponding author: Nawwar Al-Attar (nawwar.alattar@gjnh.scot.nhs.uk) \\ Fl000Prime Reports 2014, 6:92 (doi:10.12703/P6-92) \\ All Fl000Prime Reports articles are distributed under the terms of the Creative Commons Attribution-Non Commercial License \\ (http://creativecommons.org/licenses/by-nc/3.0/legalcode), which permits non-commercial use, distribution, and reproduction in any medium, \\ provided the original work is properly cited. \\ The electronic version of this article is the complete one and can be found at: http://f $1000 . c o m / p r i m e / r e p o r t s / m / 6 / 92$
}

\begin{abstract}
Transcatheter aortic valve implantation was developed to offer a therapeutic solution to patients with severe symptomatic aortic stenosis who are not candidates for conventional aortic valve replacement. The improvement in transcatheter aortic valve implantation outcomes is still of concern in the areas of stroke, vascular injury, heart block, paravalvular regurgitation and valve durability. Concomitantly, the progress, both technical and in terms of material advances of transcatheter valve systems, as well as in patient selection, renders transcatheter aortic valve implantation an increasingly viable treatment for more and more patients with structural heart disease.
\end{abstract}

\section{Introduction}

A decade ago, extremely high-risk or "inoperable" patients with aortic valve disease had few options besides palliative care. Since its introduction, transcatheter aortic valve implantation (TAVI) is now considered by some physicians as the standard of care for these patients and is a reasonable alternative to surgery for many high-risk but "operable" patients. As we pass 10 years of clinical experience with TAVI, a review of the current status is warranted.

Replacement of the aortic valve is the only effective treatment for symptomatic aortic stenosis. Surgical aortic valve replacement (AVR) has an overall low operative mortality [1]; however, elderly patients are at a much higher risk of mortality, presumably owing to the presence of multiple coexisting conditions [2]. Likewise, in patients with severe symptomatic aortic stenosis who are not candidates for surgical AVR, TAVI offers a solution by relieving the left ventricular outflow track obstruction in a durable and controlled manner, in comparison with balloon valvuloplasty [3]. In this review, we discuss the status of TAVI in clinical practice, including the evolution of approaches, current and future patient selection, available valve prosthesis and recent results.

\section{Patient selection}

An overall assessment of the patient is essential for TAVI. This involves a team of multidisciplinary members (heart team) who work as a group to review and interpret clinical data, and assess the patient from access to implantation site, to arrive at a consensus on the optimal treatment strategy for each patient. The heart team approach also allows for the adjustment of the decision-making process according to local experience and circumstances [4].

Currently, TAVI is indicated for high-risk surgical patients with severe aortic stenosis. In addition to patient risk evaluation, anatomical selection criteria need to be considered. The aorta should be evaluated with invasive angiography or contrast multislice computed tomography (CT) to assess technical issues related to the delivery and implantation of the valve, aortic root and valvular calcification, and the risk of coronary obstruction [5]. The dimensions of the aortic annulus must be evaluated in order to select an appropriately sized valve. Transoesophageal echocardiography, multislice CT, and magnetic resonance imaging (MRI) measurements are widely utilized.

The logistic EuroSCORE and the STS (Society of Thoracic Surgeons) Predicted Risk of Mortality score have guided 
enrolment of high surgical risk patients into TAVI trials. They have been integrated into a novel grid for the evaluation of surgical and interventional risk of patients with valve disease combining STS risk estimate; frailty indices (Katz Activities of Daily Living_independence in feeding, bathing, dressing, transferring, toileting and urinary continence-and independence in ambulation); major organ system dysfunction (cardiac, central nervous system [CNS], gastrointestinal, cancer and liver); and procedure-specific impediments (such as tracheostomy, heavily calcified ascending aorta, chest malformation, arterial coronary graft adherent to chest wall, or radiation damage) [6].

A simple TAVI scoring system predicting 30-day mortality was developed recently [7]. This study identified nine predictive factors of early mortality after TAVI, which are age, body mass index (BMI), NYHA (New York Heart Association) class, pulmonary edema, pulmonary hypertension, critical state, respiratory insufficiency, dialysis, and transapical approach [7]. The final risk assessment should be fashioned according to the judgment of the heart team, together with a combination of multiple risk scoring systems [8]. It may provide additional information during the pre-procedural screening process to better understand the potential outcomes of patients after TAVI [9].

\section{TAVI in "lower risk" patients}

Over the last few years, there has been a shift towards the treatment of lower risk patients. In these patients, clinical outcomes after TAVI were better than patients with higher co-morbidity [10]. The Placement of Aortic Transcatheter Valves (PARTNER) II Cohort A, the SURgical and Transcatheter Aortic Valve Implantation (SURTAVI) and the United Kingdom TAVI trials are randomized trials assessing the effectiveness of TAVI in intermediate-risk patients [11].

\section{TAVI approaches}

The most common approach for TAVI is the transfemoral approach; here the catheter is advanced to the stenotic aortic valve via the femoral artery. Valve deployment is accomplished by transcatheter introduction of a balloonor self-expandable valve [2]. Rapid ventricular pacing (180-200 beats per min) is used to reduce cardiac motion during critical deployment of the valve. Entry to the femoral artery can be achieved through surgical cut down or through a purely percutaneous approach, the latter allowing the procedure to be performed on an awake patient under loco-regional anesthesia [12]. The Achilles' heel of the femoral approach is the risk of injury to the ilio-femoral vessels.

The transapical approach was developed to replace the transfemoral route in patients with severe peripheral vascular disease [13]. Being a surgical procedure entailing opening the chest, it necessitates general anesthesia and is optimally performed in a hybrid operative suite. It employs a small left lateral thoracotomy, and subsequently uses direct puncture and sheath insertion directly into the apex of the left ventricle. A guide wire is used to cross the aortic valve and the rest of the procedure follows the same steps of valve deployment as the transfemoral approach. Benefits of transapical TAVI include more direct access to the stenotic valve and the avoidance of potential complications related to peripheral access. The transapical approach carries the risk of complications related to puncture of the left ventricle.

The transaxillary/subclavian approach is a safe alternative vascular access site in patients for whom both the transfemoral and transapical routes are contraindicated [14]. However, despite several potential advantages over the other approaches, this route for TAVI has yet to gain widespread acceptance [15].

TAVI can also be performed via the transaortic approach through a partial (J) shaped sternotomy or a right minithoracotomy, followed by a guide wire introduction into the aortic valve via the ascending aorta; this approach seems to be technically feasible and associated with favorable outcomes. The transaortic approach may be associated with lower bleeding rates, shorter intensive care unit (ICU) stay, and a more favorable learning curve for clinicians compared to the transapical approach [16].

Transcarotid approach via the common carotid artery represents a direct route to the aortic valve with a shorter distance separating the arterial entry point and the aortic annulus. Similar to transapical and transaortic accesses, this enhances sheath and delivery catheter stability and improves movement precision. Compared with transfemoral access, it renders the prosthesis positioning more accurate. This approach has been performed under local anesthesia [17].

\section{Commercially available TAVI systems}

The SAPIEN ${ }^{\circledR}$ transcatheter valve (Edwards Lifesciences, Irvine, CA, USA) is a balloon-expandable bovine pericardial tissue valve mounted on a stent frame. Initially in stainless steel, the SAPIEN XT ${ }^{\circledR}$ transcatheter heart valve (THV) has a cobalt chromium stent frame in order to increase radial strength. CoreValve ${ }^{\circledR}$ (Medtronic Inc., Minneapolis, MN, USA) has an auto-expandable nitinol stent containing a porcine pericardial valve, which allows its insertion through smaller sheath sizes. Together they form the major TAVI prostheses in clinical use and are supported by data [18-21].

New designs are available that are intended to avoid some of the complications reported with the previous 
valves, such as the risks of valve migration or suboptimal positioning necessitating a second valve deployment, significant paravalvular leak, conduction disturbances and obstruction of the coronary ostium. These valves include the Lotus ${ }^{\mathrm{TM}}$ valve (Boston Scientific, Natick, MA, USA), the Direct Flow Medical ${ }^{\circledR}$ valve (Direct Flow Medical Inc., Santa Rosa, CA, USA), the HLT ${ }^{\circledR}$ (Heart Leaflet Technologies Inc., Maple Grove, MN, USA), the Symetis Acurate $^{\mathrm{TM}}$ (Symetis SA, Ecublens, Switzerland), the JenaValve ${ }^{\mathrm{TM}}$ (JenaValve, Munich, Germany), the Engager $^{\mathrm{TM}}$ (Medtronic Inc., Minneapolis, MN, USA), the Portico valve ${ }^{\mathrm{TM}}$ (St Jude Medical, St Paul, MN, USA), and the Centera ${ }^{\mathrm{TM}}$ and SAPIEN $3^{\circledR}$ valves (Edwards Lifesciences, Irvine, CA, USA) [22-28]. In a single-center study involving three newer generation valves, transapical TAVI was performed using the Engager, JenaValve and Symetis Acurate valves. Implantation was successful in $96.5 \%$ of cases. Valve function improved significantly, with an increase in effective orifice area and a reduction in mean transvalvular gradients. Paravalvular regurgitation was none or trace in $70.3 \%$ of patients, Grade 1 in $26.1 \%$ of patients, and Grade 2 in 3.5\% of patients. No patients developed aortic regurgitation $>$ Grade 2 [29].

\section{Results and outcomes}

Results from the CHOICE randomized controlled trial were published recently. This trial compared the Edwards SAPIEN XT and the Medtronic CoreValve regarding the rate of device success and concluded that, in patients with high-risk aortic stenosis undergoing TAVI, a balloonexpandable valve (SAPIEN XT) resulted in a greater rate of device success than the self-expandable valve (CoreValve) [30]. From the results of a recent German study including 394 TAVI patients, the CoreValve was more frequently associated with more-than-mild aortic regurgitation than the SAPIEN XT valve system [31].

\section{Morbidity}

Stroke

Stroke remains a major complication following TAVI. In the PARTNER trial, the 30-day rates of major stroke in patients undergoing TAVI and surgery were $3.8 \%$ and $2.1 \%$, respectively, and these differences persisted at 2 years (7.7\% and $4.9 \%$, respectively) (Figure 1). There is substantial variability in antiplatelet and anticoagulation therapy following TAVI. Patients assigned to TAVI in PARTNER received intraprocedural heparin, followed by aspirin and clopidogrel for 6 months. Patients in the French Aortic National CoreValve and Edwards (FRANCE 2) Registry received dual antiplatelet therapy for 1 month, followed by aspirin indefinitely [32]. Further studies are needed to determine the optimal stroke-prevention strategy.
Figure I. Stroke, intention-to-treat population

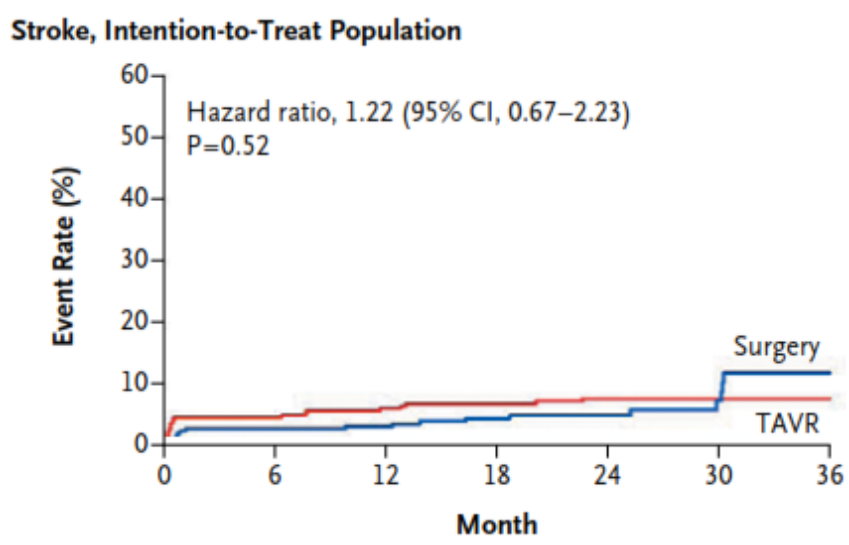

The 2 years rates of major stroke in patients undergoing TAVR and surgery are $7.7 \%$ and $4.9 \%$, respectively (PARTNER trial). Adapted with permission from [34].

Abbreviations: TAVR, transcatheter aortic valve replacement; PARTNER, Placement of Aortic Transcatheter Valves.

\section{Heart block}

Heart block, requiring permanent pacemaker implantation, is also commonly observed following TAVI, particularly with the CoreValve. In the FRANCE 2 Registry, pacemaker therapy was needed in $24.2 \%$ of patients receiving the CoreValve, compared with $11.5 \%$ with the Sapien valve [33]. The incidence of conduction abnormalities may be reduced with increasing operator experience and newer-generation devices.

\section{Paravalvular leakage}

Paravalvular leakage is more frequent and more severe following TAVI than that encountered after surgical AVR. In the PARTNER A cohort, moderate to severe paravalvular leakage occurred in $12 \%$ of patients receiving TAVI compared with $0.9 \%$ undergoing surgical AVR [34], and in the FRANCE 2 Registry, the 30-day incidence of grade 2 or higher paravalvular leakage was $17.1 \%$ [32]. Even mild paravalvular leakage, which occurs in more than $40 \%$ of patients, may be significantly associated with increased mortality [34]. Paravalvular leakage is thought to result at least in part from inappropriate sizing of the prosthesis [35]. In a meta-analysis, the pooled estimate for moderate or severe aortic regurgitation post-TAVI was $11.7 \%$. Moderate or severe aortic regurgitation was more common with use of the CoreValve (16.0\% vs. 9.1\%). The presence of moderate or severe aortic regurgitation post-TAVI increased mortality at 30 days and 1 year [36].

As TAVI technology evolves toward smaller device sizes, problems such as vascular complications or major bleeding are expected to decrease significantly. In the randomized 
controlled PARTNER trial, thirty-day rates of major bleeding complications were assessed in 657 patients from Cohort A: $71(22.7 \%), 27(11.3 \%)$, and 9 (8.8\%) patients had major bleeding within 30 days of the procedure after surgical AVR, transfemoral TAVI and transapical TAVI, respectively [37].

\section{Mortality}

In the $\mathrm{B}$ cohort of the PARTNER trial, patients were considered inoperable if at least two cardiac surgeons agreed that patients had comorbid conditions associated with a $\geq 50 \%$ predicted rate of death or irreversible complications at 30 days with conventional surgical AVR, and patients were then randomly assigned to undergo standard medical therapy or TAVI. At 2-year follow up, allcause mortality rates in the TAVI group and the standard therapy group were $43.4 \%$ and $67.6 \%$, respectively [38].

The PARTNER A cohort comprised patients with severe aortic stenosis who were considered high risk for conventional surgical AVR, defined by an STS risk score of $\geq 10 \%$, or estimated probability of 30-day postoperative mortality of $15 \%$ or more, based on comorbidities $[39,40]$. Patients were randomly assigned to undergo TAVI or conventional surgical AVR. There was no statistically significant difference in the rates of all-cause mortality at 2 years $(33.9 \%$ in TAVI and 35.0\% with surgical AVR) (Figure 2) [34]. Both treatment modalities appeared to effectively reduce the transvalvular mean pressure gradient [41].

In a recent randomized multicenter trial involving 795 high surgical risk patients [42], TAVI with CoreValve was

Figure 2. Death from any cause, intention-to-treat population



No statistically significant difference was seen between TAVR and surgical aortic valve replacement groups in the rates of all-cause mortality at 2 years (PARTNER trial). Adapted with permission from [34].

Abbreviations: TAVR, transcatheter aortic valve replacement; PARTNER, Placement of Aortic Transcatheter Valves. associated with a significantly higher rate of survival at 1 year in comparison to surgical AVR (Figure 3) [42].

Data from the United Kingdom TAVI Registry were collected prospectively and included 870 patients undergoing 877 TAVI procedures up until 31 December 2009. Mortality tracking was achieved in $100 \%$ of patients, with mortality status reported as of December 2010. Survival at 30 days, 1 year and 2 years was $92.9 \%, 78.6 \%$ and $73.7 \%$, respectively [43].

The results from databases of four experienced European centers were pooled and analyzed. 793 patients were included: $453(57.1 \%)$ treated with the Medtronic CoreValve and 340 (42.9\%) with the Edwards SAPIEN/ SAPIEN XT. After propensity matching, 204 patients were identified in each group. At 30 days, there were no differences in all-cause mortality, cardiovascular mortality, myocardial infarction, stroke, or device success [44].

\section{Transfemoral vs. transapical implantation}

In a large multicenter collaborative study, a total of 882 patients underwent TAVI, of whom 793 (89.9\%) underwent transfemoral TAVI and 89 (10.1\%) underwent transapical TAVI. At 30 days, there was an increased risk of all-cause mortality in the transapical TAVI group. Transfemoral TAVI was associated with a higher frequency of minor vascular complications. Hospital stay was significantly longer among patients undergoing transapical TAVI. During a median follow-up of 365 days, transapical TAVI was associated with an increased risk of all-cause mortality [45]. Improved outcomes can be expected by improving patient selection, by individual centers scaling

Figure 3. Kaplan-Meier cumulative frequency of death from any cause

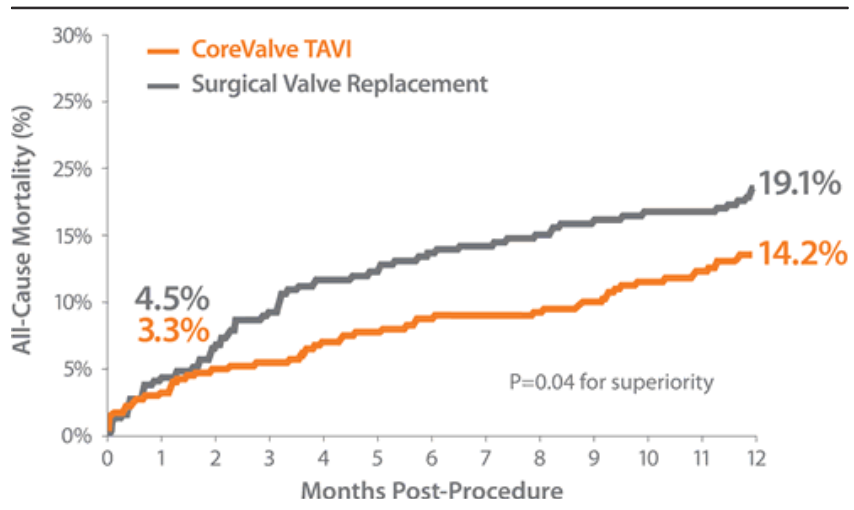

TAVI was associated with a significantly higher rate of survival at I year in comparison to surgical aortic valve replacement (CoreValve Trial). Adapted with permission from [42].

Abbreviations: TAVI, transcatheter aortic valve implantation. 
the procedural learning curve, and by refinements in surgical technique [46].

\section{Valve-in-valve TAVI}

TAVI might be of value for the treatment of failed surgically implanted bioprostheses. Small case series studies have recently provided evidence about the feasibility of this treatment [47-49]. CoreValve has been CE marked for valve-in-bioprosthetic valve TAVI. Although promising, more data are needed to confirm the efficacy of TAVI in this setting, and further research is required to optimize valve-in-valve implantation before this treatment can be considered as a valid alternative [50].

\section{Conclusion}

Patients with severe symptomatic aortic stenosis can be offered either surgical AVR or TAVI depending on their surgical risk; both techniques establish hemodynamic correction of the aortic valve function. The choice should be patient centered and made after assessment by the heart team. Valves and delivery systems are continually refined to allow for less invasive procedures and facilitated implantation. Additional areas of active research include strategies for stroke prevention, including defining the optimal antiplatelet and anticoagulant regimen after TAVI, as well as the use of embolic protection devices.

\section{Abbreviations}

AVR, aortic valve replacement; CT, computed tomography; PARTNER, Placement of Aortic Transcatheter Valves; STS, Society of Thoracic Surgeons; TAVI, transcatheter aortic valve implantation.

\section{Disclosures}

The authors declare that they have no disclosures.

\section{References}

I. Edwards FH, Peterson ED, Coombs LP, DeLong ER, Jamieson WR, Shroyer ALW, Grover FL: Prediction of operative mortality after valve replacement surgery. J Am Coll Cardiol 200 I, 37:885-92.

2. Iribarne A, Easterwood R, Chan, Edward Y H, Yang J, Soni L, Russo MJ, Smith CR, Argenziano M: The golden age of minimally invasive cardiothoracic surgery: current and future perspectives. Future Cardiol 20I I, 7:333-46.

3. Zajarias A, Cribier AG: Outcomes and safety of percutaneous aortic valve replacement. J Am Coll Cardiol 2009, 53:I829-36.

4. Folliguet T, Al-Attar N: Implementing the Heart team Approach for Optimal Strategy in Myocardial Revascularization and Structural Valve Disease. In PanVascular Medicine. $2^{\text {nd }}$ edition. Edited by Lanzer P. Berlin: Springer; in press.

5. Webb JG, Wood DA: Current status of transcatheter aortic valve replacement. J Am Coll Cardiol 20I2, 60:483-92.

6. Nishimura RA, Otto CM, Bonow RO, Carabello BA, Erwin JP, Guyton RA, O'Gara PT, Ruiz CE, Skubas NJ, Sorajja P, Sundt TM, Thomas JD: 2014 AHA/ACC Guideline for the Management of Patients With Valvular Heart Disease: Executive Summary: A Report of the American College of Cardiology/American
Heart Association Task Force on Practice Guidelines. I Am Coll Cardiol 2014.

FlOOOPrime

7. lung $B$, Laouénan $C$, Himbert D, Eltchaninoff H, Chevreul K, DonzeauGouge P, Fajadet J, Leprince P, Leguerrier A, Lièvre M, Prat A, Teiger E, Laskar M, Vahanian A, Gilard M: Predictive factors of early mortality after transcatheter aortic valve implantation: individual risk assessment using a simple score. Heart 2014, 100:1016-23.

\section{FIOOOPrime
RECOMMENDED}

8. Vahanian A, Alfieri O, Andreotti F, Antunes MJ, Barón-Esquivias G, Baumgartner H, Borger MA, Carrel TP, Bonis M de, Evangelista A, Falk V, Lung B, Lancellotti P, Pierard L, Price S, Schäfers H, Schuler G, Stepinska J, Swedberg K, Takkenberg J, Von Oppell, Ulrich Otto, Windecker S, Zamorano JL, Zembala M: Guidelines on the management of valvular heart disease (version 20 I2): the Joint Task Force on the Management of Valvular Heart Disease of the European Society of Cardiology (ESC) and the European Association for Cardio-Thoracic Surgery (EACTS). Eur J Cardiothorac Surg 2012, 42:SI-44.

\section{FlOOOPrime}

\section{RECOMMENDED}

9. Piazza N, Lange R, Martucci G, Serruys PW: Patient selection for transcatheter aortic valve implantation: patient risk profile and anatomical selection criteria. Arch Cardiovasc Dis 2012, 105:165-73.

10. Lange R, Bleiziffer S, Mazzitelli D, Elhmidi $Y$, Opitz A, Krane M, Deutsch M, Ruge H, Brockmann G, Voss B, Schreiber C, Tassani P, Piazza N: Improvements in transcatheter aortic valve implantation outcomes in lower surgical risk patients: a glimpse into the future. J Am Coll Cardiol 2012, 59:280-7.

II. Bourantas CV, Farooq V, Onuma Y, Piazza N, Van Mieghem, Nicolas M, Serruys PW: Transcatheter aortic valve implantation: new developments and upcoming clinical trials. Eurolntervention 20I2, 8:617-27.

12. Guinot $P$, Depoix J, Etchegoyen L, Benbara A, Provenchère $S$, Dilly $M$, Philip I, Enguerand D, Ibrahim H, Vahanian A, Himbert D, Al-Attar N, Nataf P, Desmonts J, Montravers P, Longrois D: Anesthesia and perioperative management of patients undergoing transcatheter aortic valve implantation: analysis of 90 consecutive patients with focus on perioperative complications. J Cardiothorac Vasc Anesth 2010, 24:752-6I.

13. Al-Attar N, Himbert D, Descoutures F, lung B, Raffoul R, MessikaZeitoun D, Brochet E, Francis F, Ibrahim H, Vahanian A, Nataf P: Transcatheter aortic valve implantation: selection strategy is crucial for outcome. Ann Thorac Surg 2009, 87: 1757-62.

FlOOOPrime

14. Caceres M, Braud R, Roselli EE: The axillary/subclavian artery access route for transcatheter aortic valve replacement: a systematic review of the literature. Ann Thorac Surg 20 I 2, 93: I $013-8$.

\section{FlOOOPrime}

RECOMMENDED

15. Laflamme M, Mazine A, Demers P, Lamarche $Y$, Ibrahim R, Asgar A, Cartier R: Transcatheter aortic valve implantation by the left axillary approach: a single-center experience. Ann Thorac Surg 2014, 97:1549-54.

16. Lardizabal JA, O'Neill BP, Desai HV, Macon CJ, Rodriguez AP, Martinez CA, Alfonso CE, Bilsker MS, Carillo RG, Cohen MG, Heldman AW, O'Neill WW, Williams DB: The transaortic approach for transcatheter aortic valve replacement: initial clinical experience in the United States. J Am Coll Cardiol 20I3, 6I:234I-5.

\section{FlOOOPrime}

17. Azmoun A, Amabile N, Ramadan R, Ghostine S, Caussin C, Fradi S, Raoux F, Brenot P, Nottin R, Deleuze P: Transcatheter aortic valve implantation through carotid artery access under local anaesthesia. Eur J Cardiothorac Surg 2014. 
18. Tzikas A, van Dalen, Bas M, Van Mieghem, Nicolas M, GutierrezChico J, Nuis R, Kauer F, Schultz C, Serruys PW, de Jaegere, Peter P T, Geleijnse ML: Frequency of conduction abnormalities after transcatheter aortic valve implantation with the MedtronicCoreValve and the effect on left ventricular ejection fraction. Am J Cardiol 20I I, 107:285-9.

19. Stabile E, Sorropago G, Cioppa A, Cota L, Agrusta M, Lucchetti V, Rubino P: Acute left main obstructions following TAVI. Eurolntervention 2010, 6:100-5.

20. Sinning J, Hammerstingl C, Vasa-Nicotera $M$, Adenauer $V$, Lema Cachiguango, Sisa Josefina, Scheer A, Hausen S, Sedaghat A, Ghanem A, Müller C, Grube E, Nickenig G, Werner N: Aortic regurgitation index defines severity of peri-prosthetic regurgitation and predicts outcome in patients after transcatheter aortic valve implantation. J Am Coll Cardiol 20 I2, 59: I I34-4I.

21. Petronio AS, Giannini C, Carlo M de: Mechanisms and prediction of aortic regurgitation after TAVI. Eurolntervention 20 I2, 8 Suppl Q: Q18-20.

22. Willson AB, Rodès-Cabau J, Wood DA, Leipsic J, Cheung A, Toggweiler S, Binder RK, Freeman M, DeLarochellière R, Moss R, Nombela-Franco L, Dumont E, Szummer K, Fontana GP, Makkar R, Webb JG: Transcatheter aortic valve replacement with the St. Jude Medical Portico valve: first-in-human experience. J Am Coll Cardiol 2012, 60:58I-6.

23. Sinning J, Werner N, Nickenig G, Grube E: Medtronic CoreValve Evolut valve. Eurolntervention 2012, 8 Suppl Q:Q94-6.

24. Kempfert J, Treede H, Rastan AJ, Schönburg M, Thielmann M, Sorg S, Mohr F, Walther T: Transapical aortic valve implantation using a new self-expandable bioprosthesis (ACURATE TA ${ }^{\mathrm{TM}}$ ): 6-month outcomes. Eur J Cardiothorac Surg 2013, 43:52-6; discussion 57.

\section{FlOOOPrime}

25. Treede H, Mohr F, Baldus S, Rastan A, Ensminger S, Arnold M, Kempfert J, Figulla $\mathrm{H}$ : Transapical transcatheter aortic valve implantation using the JenaValve ${ }^{\mathrm{TM}}$ system: acute and 30-day results of the multicentre CE-mark study. Eur J Cardiothorac Surg 20I2, 4I:el3|-8.

26. Falk V, Walther T, Schwammenthal E, Strauch J, Aicher D, Wahlers T, Schäfers J, Linke A, Mohr FW: Transapical aortic valve implantation with a self-expanding anatomically oriented valve. Eur Heart J 20II, 32:878-87.

27. Bijuklic K, Tuebler $\mathrm{T}$, Reichenspurner $\mathrm{H}$, Treede $\mathrm{H}$, Wandler $\mathrm{A}$, Harreld JH, Low RI, Schofer J: Midterm stability and hemodynamic performance of a transfemorally implantable nonmetallic, retrievable, and repositionable aortic valve in patients with severe aortic stenosis. Up to 2-year follow-up of the direct-flow medical valve: a pilot study. Circ Cardiovasc Interv 20I I, 4:595-60I.

28. Meredith IT: Repositionable percutaneous replacement of a stenotic aortic valve through implantation of the Lotus valve system: discharge/7-day outcome in the REPRISE I study. Presented at Proceedings of the Euro; PCR I5-I8 May 2012; Paris, France.

29. Seiffert M, Conradi L, Kloth B, Koschyk D, Schirmer J, Schnabel RB, Blankenberg S, Reichenspurner H, Diemert P, Treede H: Single-centre experience with next-generation devices for transapical aortic valve implantation. Eur J Cardiothorac Surg 20 I4, [Epub ahead of print].

\section{FlOOOPrime \\ RECOMMENDED}

30. Abdel-Wahab M, Mehilli J, Frerker C, Neumann F, Kurz T, Tölg R, Zachow D, Guerra E, Massberg S, Schäfer U, El-Mawardy M, Richardt G: Comparison of balloon-expandable vs self-expandable valves in patients undergoing transcatheter aortic valve replacement: the CHOICE randomized clinical trial. JAMA 20 I4, 3 II:I503-I4.

\section{FlOOOPrime}

\section{RECOMMENDED}

31. Abdel-Wahab M, Comberg T, Büttner HJ, El-Mawardy M, Chatani K, Gick M, Geist V, Richardt G, Neumann F: Aortic regurgitation after transcatheter aortic valve implantation with balloon- and self-expandable prostheses: a pooled analysis from a 2-center experience. JACC Cardiovasc Interv 2014, 7:284-92

\section{FlOOOPrime}

32. Gilard $M$, Eltchaninoff $H$, lung $B$, Donzeau-Gouge $P$, Chevreul K, Fajadet I, Leprince P, Leguerrier A, Lievre M, Prat A, Teiger E, Lefevre T, Himbert D, Tchetche D, Carrié D, Albat B, Cribier A, Rioufol G, Sudre A, Blanchard D, Collet F, Dos Santos P, Meneveau N, Tirouvanziam A, Caussin C, Guyon P, Boschat J, Le Breton H, Collart F, Houel R et al:: Registry of transcatheter aortic-valve implantation in high-risk patients. N Engl J Med 20I2, 366: I705-I5.

\section{FlOOOPrime \\ RECOMMENDED}

33. Généreux P, Head SJ, Hahn R, Daneault B, Kodali S, Williams MR, Van Mieghem, Nicolas M, Alu MC, Serruys PW, Kappetein AP, Leon MB: Paravalvular leak after transcatheter aortic valve replacement: the new Achilles' heel? A comprehensive review of the literature. J Am Coll Cardiol 2013, 6 I: I 125-36.

\section{FlOOOPrime \\ RECOMMENDED}

34. Kodali SK, Williams MR, Smith CR, Svensson LG, Webb JG, Makkar RR, Fontana GP, Dewey TM, Thourani VH, Pichard AD, Fischbein M, Szeto WY, Lim S, Greason KL, Teirstein PS, Malaisrie SC, Douglas PS, Hahn RT, Whisenant B, Zajarias A, Wang D, Akin JJ, Anderson WN, Leon MB: Two-year outcomes after transcatheter or surgical aortic-valve replacement. N Engl J Med 2012, 366:1686-95.

\section{FlOOOPrime
RECOMMENDED}

35. Desai CS, Roselli EE, Svensson LG, Bonow RO: Transcatheter aortic valve replacement: current status and future directions. Semin Thorac Cardiovasc Surg 2013, 25:193-6.

36. Athappan G, Patvardhan E, Tuzcu EM, Svensson LG, Lemos PA Fraccaro C, Tarantini G, Sinning J, Nickenig G, Capodanno D, Tamburino C, Latib A, Colombo A, Kapadia SR: Incidence, predictors, and outcomes of aortic regurgitation after transcatheter aortic valve replacement: meta-analysis and systematic review of literature. J Am Coll Cardiol 2013, 61: 1585-95.

\section{FIOOOPrime}

RECOMMENDED

37. Généreux P, Cohen DJ, Williams MR, Mack M, Kodali SK, Svensson LG, Kirtane AJ, Xu K, McAndrew TC, Makkar R, Smith CR, Leon MB: Bleeding complications after surgical aortic valve replacement compared with transcatheter aortic valve replacement: insights from the PARTNER I Trial (Placement of Aortic Transcatheter Valve). J Am Coll Cardiol 2014, 63: I 100-9.

\section{FlOOOPrime
RECOMMENDED}

38. Makkar RR, Fontana GP, jilaihawi H, Kapadia S, Pichard AD, Douglas PS, Thourani VH, Babaliaros VC, Webb JG, Herrmann HC, Bavaria JE, Kodali S, Brown DL, Bowers B, Dewey TM, Svensson LG, Tuzcu M, Moses JW, Williams MR, Siegel RJ, Akin JJ, Anderson WN, Pocock S, Smith CR, Leon MB: Transcatheter aortic-valve replacement for inoperable severe aortic stenosis. N EnglJ Med 2012, 366: 1696-704.

\section{FlOOOPrime \\ RECOMMENDED}

39. Leon MB, Smith CR, Mack M, Miller DC, Moses JW, Svensson LG, Tuzcu EM, Webb JG, Fontana GP, Makkar RR, Brown DL, Block PC, Guyton RA, Pichard AD, Bavaria JE, Herrmann HC, Douglas PS, Petersen JL, Akin JJ, Anderson WN, Wang D, Pocock S: Transcatheter aortic-valve implantation for aortic stenosis in patients who cannot undergo surgery. N Engl J Med 2010, 363:1597-607.

\section{FlOOOPrime
RECOMMENDED}

40. Smith CR, Leon MB, Mack MJ, Miller DC, Moses JW, Svensson LG, Tuzcu EM, Webb JG, Fontana GP, Makkar RR, Williams M, Dewey T, Kapadia S, Babaliaros V, Thourani VH, Corso P, Pichard AD, Bavaria JE, Herrmann HC, Akin JJ, Anderson WN, Wang D, 
Pocock S]: Transcatheter versus surgical aortic-valve replacement in high-risk patients. N Engl J Med 20II, 364:2187-98.

\section{FlOOOPrime}

41. Cao C, Ang SC, Indraratna P, Manganas C, Bannon P, Black D, Tian D, Yan TD: Systematic review and meta-analysis of transcatheter aortic valve implantation versus surgical aortic valve replacement for severe aortic stenosis. Ann Cardiothorac Surg 20 I3, 2: 10-23.

\section{FlOOOPrime \\ RECOMMENDED}

42. Adams DH, Popma |], Reardon MJ, Yakubov S], Coselli JS, Deeb GM, Gleason TG, Buchbinder M, Hermiller J, Kleiman NS, Chetcuti S, Heiser J, Merhi W, Zorn G, Tadros P, Robinson N, Petrossian G, Hughes GC, Harrison JK, Conte J, Maini B, Mumtaz M, Chenoweth S, Oh JK: Transcatheter aortic-valve replacement with a self-expanding prosthesis. N Engl J Med 20I4, 370: 1790-8.

\section{FlOOOPrime \\ RECOMMENDED}

43. Moat NE, Ludman P, de Belder, Mark A, Bridgewater B, Cunningham AD, Young CP, Thomas M, Kovac J, Spyt T, MacCarthy PA, Wendler O, Hildick-Smith D, Davies SW, Trivedi U, Blackman DJ, Levy RD, Brecker, Stephen J D, Baumbach A, Daniel T, Gray H, Mullen MJ: Long-term outcomes after transcatheter aortic valve implantation in high-risk patients with severe aortic stenosis: the U.K. TAVI (United Kingdom Transcatheter Aortic Valve Implantation) Registry. J Am Coll Cardiol 20I I, 58:2130-8.

\section{FlOOOPrime}

\section{RECOMMENDED}

44. Chieffo A, Buchanan GL, Van Mieghem, Nicolas M, Tchetche D, Dumonteil N, Latib A, van der Boon, Robert M A, Vahdat O, Marcheix B, Farah B, Serruys PW, Fajadet J, Carrié D, de Jaegere, Peter P T, Colombo A: Transcatheter aortic valve implantation with the Edwards SAPIEN versus the Medtronic CoreValve Revalving system devices: a multicenter collaborative study: the PRAGMATIC Plus Initiative (Pooled-RotterdAm-Milano-Toulouse In Collaboration). J Am Coll Cardiol 2013, 61:830-6.

FlOOOPrime
45. van der Boon, Robert M A, Marcheix B, Tchetche D, Chieffo A, Van Mieghem, Nicolas M, Dumonteil N, Vahdat O, Maisano F, Serruys PW, Kappetein AP, Fajadet J, Colombo A, Carrié D, van Domburg, Ron T, de Jaegere, Peter P T: Transapical versus transfemoral aortic valve implantation: a multicenter collaborative study. Ann Thorac Surg 2014, 97:22-8.

\section{FlOOOPrime}

\section{RECOMMENDED}

46. Dewey TM, Bowers B, Thourani VH, Babaliaros V, Smith CR, Leon MB, Svensson LG, Tuzcu EM, Miller DC, Teirstein PS, Tyner J, Brown DL, Fontana GP, Makkar RR, Williams MR, George I, Kirtane AJ, Bavaria JE, Mack MJ: Transapical aortic valve replacement for severe aortic stenosis: results from the nonrandomized continued access cohort of the PARTNER trial. Ann Thorac Surg 2013, 96:2083-9.

47. Dvir D, Webb J, Brecker S, Bleiziffer S, Hildick-Smith D, Colombo A, Descoutures F, Hengstenberg C, Moat NE, Bekeredjian R, Napodano M, Testa L, Lefevre T, Guetta V, Nissen H, Hernández J, Roy D, Teles RC, Segev A, Dumonteil N, Fiorina C, Gotzmann M, Tchetche D, Abdel-Wahab M, Marco F de, Baumbach A, Laborde J, Kornowski R: Transcatheter aortic valve replacement for degenerative bioprosthetic surgical valves: results from the global valve-in-valve registry. Circulation 20।2, 126:2335-44

48. Piazza N, Bleiziffer S, Brockmann G, Hendrick R, Deutsch M, Opitz A, Mazzitelli D, Tassani-Prell P, Schreiber C, Lange R: Transcatheter aortic valve implantation for failing surgical aortic bioprosthetic valve: from concept to clinical application and evaluation (part 2). JACC Cardiovasc Interv 20I I, 4:733-42.

49. Webb JG, Wood DA, Ye J, Gurvitch R, Masson J, Rodés-Cabau J, Osten M, Horlick E, Wendler O, Dumont E, Carere RG, Wijesinghe N, Nietlispach F, Johnson M, Thompson CR, Moss R, Leipsic J, Munt B, Lichtenstein SV, Cheung A: Transcatheter valve-in-valve implantation for failed bioprosthetic heart valves. Circulation 2010, 12 1:1848-57.

\section{FlOOOPrime}

\section{PECOMMENDED}

50. Bourantas CV, Van Mieghem, Nicolas M, Farooq V, Soliman OI, Windecker S, Piazza N, Serruys PW: Future perspectives in transcatheter aortic valve implantation. Int J Cardiol 20 I3, I68: I I-8. 